

\title{
The Effect of Nominal Exchange Rate Volatility on Real Macroeconomic Performance in the CEE Countries *
}

\author{
Olga Arratibel ${ }^{\#}$, Davide Furceri ${ }^{+\%}$, Reiner Martin ${ }^{\#}$, \\ Aleksandra Zdzienicka ${ }^{\infty}$
}

\begin{abstract}
This paper analyzes the relation between nominal exchange rate volatility and several macroeconomic variables, namely real per output growth, excess credit, foreign direct investment (FDI) and the current account balance, in the Central and Eastern European EU Member States. Using panel estimations for the period between 1995 and 2008, we find that lower exchange rate volatility is associated with higher growth, higher stocks of FDI, higher current account deficits, and higher excess credit. The results are economically and statistically significant, and robust.
\end{abstract}

JEL: F3, F4, F5.

Keywords: EU, Exchange Rate Volatility, Growth, FDI, Credit, Current Account.

\footnotetext{
* We are grateful to Christophe Kamps, Hans-Joachim Klöckers, Carolin Nerlich, Philipp Rother and two anonymous referees for useful comments on earlier versions of this paper. The opinions expressed herein are those of the authors and do not necessarily reflect those of the ECB or the Eurosystem, the OECD and its member countries.

\# European Central Bank, Directorate General Economics, Kaiserstraße 29, D-60311 Frankfurt am Main, Germany, email: olga.arratibel@ecb.europa.eu.

+ University of Palermo, Department of Economics, Italy. Email:furceri@economia.unipa.it.

\% OECD, Macroeconomic Analysis Division, 2 rue André-Pascal, 75775 Paris Cedex 16, France, email: davide.furceri@OECD.org.

\# European Central Bank, Directorate General Economics, Kaiserstraße 29, D-60311 Frankfurt am Main, Germany, email: reiner.martin@ecb.europa.eu.

${ }^{\infty}$ CNRS, UMR 5824, GATE, Ecully, F-69130, France; Corresponding adress: ENS-LSH, GATE, 15 parvis René Descartes, BP 700069342 Lyon Cedex, France, Email: azdzieni@ens-lsh.fr.
} 


\section{Introduction}

Monetary policy strategies in the Central and Eastern European EU Member States (hereafter CEE) differ considerably, from completely fixed exchange rate arrangements to pure floaters. At the beginning of the transition process, most of these countries relied on pegging the exchange rate to a highly stable currency, such as the US dollar or the Deutsche Mark, as a way to (i) achieve macroeconomic stabilization by means of a rapid disinflation process ("hard-pegs" as an external nominal anchor), and (ii) to facilitate the transition process from centrally planned to market economies, in the absence of fully developed markets and institutions ("hard-pegs" as an institutional device). However, by the beginning of this century, once macroeconomic stability was broadly achieved, a number of CEE countries gradually softened their pegs and moved towards more monetary policy autonomy; countries that did so adopted inflation targeting as a monetary policy framework. "Hard-pegs" made a significant contribution to restoring market confidence during the early period of transition.

More recently, the particular policy challenges facing the CEE countries that operate "hard-pegs" have come to the forefront. Following the strong increase in the internal and external imbalances in the Baltic States and Bulgaria in the period up until 2008 they are now experiencing a very rapid economic adjustment period with deep recessions. Latvia even had to take recourse to an international financial support package led by the IMF in late 2008 .

From a theoretical point of view, there is not a clear consensus on the best exchange rate regime for macroeconomic performance. Proponents of fixed exchange rate regimes argue that exchange rate stability promotes economic performance through higher trade and enhanced macroeconomic stability which could favour foreign investment and growth, while impacting on investment and saving decisions (therefore affecting current 
account) and financial development. In contrast, proponents of flexible exchange rate regimes traditionally emphasize the advantage of exchange rate flexibility to correct for domestic and external disequilibria in the face of real asymmetric shocks.

This paper analyzes the relation between exchange rate volatility and several macroeconomic variables, namely real output growth, excess credit, the stock of inward foreign direct investment (FDI) and the current account balance, in the CEE countries. Using panel estimations for the period between 1995 and 2008, we find that lower exchange rate volatility is associated with higher growth, higher stocks of FDI, higher current account deficits, and, in general, higher excess credit. The results are economically and statistically significant, and robust.

The paper is organized as follows. The next section presents some stylized facts regarding the exchange rate strategies and macroeconomic performance for the CEE countries. Section 3 discusses the theoretical arguments for the relation between exchange rate volatility and the selected macroeconomic variables, and tests these relations in the CEE countries. Section 4 summarizes the main findings.

\section{Exchange rate regimes and real convergence in the CEE countries - stylized facts}

Exchange rate strategies in the CEE differ considerably, from fixed exchange rate to pure floaters. At the beginning of the transition process, most CEE countries relied on pegging the exchange rate to a highly stable currency, such as the US dollar or the Deutsche Mark, as a way to import credibility from abroad and to reduce inflation from high levels. In the course of the 1990s, however, a number of countries gradually softened their peg and moved towards more monetary policy autonomy, and several countries adopted inflation targeting as a monetary policy framework (Table 1). In what follows, countries are subdivided into those with "hard-peg" regimes (i.e. Bulgaria, Estonia, Latvia 
and Lithuania) and those with inflation targeting regimes combined with flexible exchange rates or relatively "soft-pegs" ("floaters"), i.e. the Czech Republic, Hungary, Poland, Romania and Slovakia. ${ }^{1}$

Looking first at real GDP growth, while both groups show a clear upward trend until the 'crisis year' 2008, the "hard-peg" countries performed better than the "floaters" in most years (Figure 1). However, while the gap in growth rates between the two groups slightly increased to around three percentage points up to 2006, it virtually closed again at the end of our sample period (i.e. in 2008).

A similar pattern emerges with regard to total domestic credit-to-GDP growth (Figure 2). Especially after the Russian crisis and up to 2006, annual credit-to-GDP growth accelerated in both sets of countries, particularly in the "hard-pegs". In fact, during 19992006 annual credit growth increased, on average, from around 14\% in 1998 to more than 33\% in 2006 in the "hard-pegs", and from around 17\% in 1998 to around $21 \%$ in 2006 in the "floaters". Having said that, credit growth has stabilized in recent years in the "floaters" and has decelerated significantly in the "hard peg" countries.

As regards the ability to attract FDI, both sets of countries, with no particular difference, were able to build-up significant stocks of inward FDI over the overall period (Figure 3-4). For FDI inflows, however, a small deceleration is observed for 2007-2008 in both sets of countries, notably the "hard-pegs".

A sharply different pattern emerges as regards the current account balance. Looking at Figure 5, the "hard-pegs" show much more sizeable external imbalances during most years. Current account imbalances consistently widened in the "hard-peg" countries,

\footnotetext{
${ }^{1}$ Most CEE countries, particularly the "floaters", have revised their exchange rate regime on several occasions over the period under study. This, however, does not change the classification of the countries under study between the two groups over the period 1995-2008. The only exception is Bulgaria, which introduced a currency board to the Deutsche Mark (euro since 1999) only on 1 July 1997. Slovakia adopted the euro as of 1 January 2009.
} 
especially from 2004 to 2006, until 2007 before narrowing in 2008 against the background of decelerating GDP growth and imports. By contrast, external imbalances remained rather constant in the "floaters".

In sum, when looking at these stylized facts over the period 1995-2008, the main differences between the two groups are that "hard-pegs" experienced faster real GDP and credit growth and significantly higher external imbalances than "floaters". Following the global financial crisis "hard-pegs" also seem to have experienced a more severe adjustment process than the "floaters".

\section{Empirical Analysis}

\subsection{Sample selection and volatility measures}

In order to estimate the relation between exchange rate regimes and key economic indicators, an important decision to be made is the underlying definition of exchange rate volatility. While exchange rate arrangements are often divided into "hard pegs" and "floaters" (as in Section 2 of this paper), there is a broad variety of "intermediate" regimes. ${ }^{2}$ De jure exchange rate classifications, such as that of the IMF, depend on the countries' ex ante self-assessment of their exchange rate regime. However, such classifications may well fail to control for a possible discrepancy between de jure and de facto regimes. Such a discrepancy has often arisen from the so-called "fear of floating", leading countries to pursue exchange rate stabilization even when they declare their exchange rate regime to be flexible (see Calvo and Reinhart, 2002; McKinnon and

\footnotetext{
${ }^{2}$ The official (IMF) classification of exchange rate arrangements, as published in the IMF Annual Report on Exchange Rate Arrangements and Exchange Restrictions, provides a measure for the commitment by the monetary authorities to an specified exchange rate regime. The IMF classifies de jure exchange rate arrangements into eight groups with a rising degree of exchange rate flexibility: 1) exchange rate regime with no separate legal tender; 2) currency board arrangements; 3 ) other conventional fixed peg arrangements (with a band of at most $\pm 1 \%$ ); 4) pegged exchange rate arrangements with horizontal bands (at least $\pm 1 \%$ ); 5) crawling pegs (with small, preannounced adjustment); 6) exchange rates with crawling bands; 7) managed floating with no preannounced path for exchange rate; 8) independent floating (market-determined exchange rate and independent monetary policy).
} 
Schnabl, 2004; De Grauwe and Schnabl, 2005). In this respect, de facto measures for exchange rate volatility provide more accurate information to assess the relation between exchange rate volatility and key macroeconomic variables.

The measure of de facto exchange rate volatility against the euro that we use in our empirical analysis is the z-scores measure proposed by Ghosh, Gulde and Wolf (2003). It incorporates both exchange rate fluctuations around a constant level and exchange rate fluctuations around a gradual depreciation/appreciation rate:

$$
z_{t}=\sqrt{\mu_{t}^{2}+\sigma_{t}^{2}}
$$

where $\mu_{t}$ corresponds to the arithmetic average of month-to-month changes in the nominal exchange rate vis-à-vis the euro in year $t$, in percentage, and $\sigma_{t}$ is the standard deviation of the month-to month changes, of the nominal exchange rate vis-à-vis the euro of the year $t$, in percentage. ${ }^{3}$

In the remainder of this section we explore the relation between exchange rate volatility and a number of key macroeconomic indicators, namely real per capita output growth, excess credit, the stock of inward FDI, and the current account balance. We use the fixed effect estimator in order to control for heterogeneity among countries and time periods, and the "sandwich" estimator for the variance and covariance matrix to control for heteroskedasticity and autocorrelation in the error components. For each of the macroeconomic variables under investigation, we use those control variables that the literature has generally found to be significant in explaining the behavior of the respective dependent variable under investigation. We also test for endogeneity of exchange rate volatility and the other controls that enter in the regressions, and when there is evidence of

\footnotetext{
${ }^{3}$ The z-scores measure in our example is highly and positively correlated to the standard deviation of the exchange rate $\left(\sigma_{t}\right)$. Thus, the use of z-scores - which includes a combination of standard deviation and changes of the exchange rate level - or $\sigma_{t}$, as an alternative volatility measure, is quite indifferent.
} 
endogeneity we use IV estimations by instrumenting the endogenous variables with their past lags. ${ }^{4}$

Our sample consists of nine CEE countries: the "hard-pegs" Bulgaria, Estonia, Latvia and Lithuania, and the "floaters" Czech Republic, Hungary, Poland, Romania and Slovakia. The data sources are IMF International Financial Statistics, EUROSTAT, and UNCTAD. Since the dataset for the cross-country panel is very fragmented until 1994, our analysis period starts in 1995 and ends in 2008. This sample period excludes most of the macroeconomic turbulences that characterized the early transformation years, and for which data are not available.

\subsection{Output Growth and Nominal Exchange Rate Volatility}

This section investigates the effects of exchange rate volatility on the CEE countries' growth performance. Traditionally, the literature provides little guidance on this subject. Some empirical literature stipulates the absence of a robust relation between exchange rate volatility (stability) and economic performance (Baxter and Stockman, 1989; Gosh, Gulde and Wolf, 2003). In contrast, other authors underline that this relation exists, at least for some groups of countries (Husain, Mody and Rogoff, 2005), but their opinions differ about the way in which exchange rate volatility affects economic growth.

Proponents of fixed exchange rate regime argue that nominal exchange rate stability promotes growth through trade (Rose, 2000; Frankel and Rose, 2002) and macroeconomic stability. Their main argument is that fixed exchange rates reduce uncertainty. A decline in exchange rate uncertainty also enhances price transparency increasing the efficiency of price mechanisms at international level (De Grauwe, 2005; Schnabl, 2007). Lower transaction costs and greater prices transparency also affect growth

\footnotetext{
4 The number of lags has been chosen to equal one. The Stock-Staiger test for valid instruments has been carried and all instruments appeared to be "strong".
} 
performance by increasing capital markets efficiency in capital allocation (McKinnon, 1973) and by lowering risk premia and real interest rates (Dornbush, 2001). In addition, if there are credit constraints, or if investment is irreversible, lower aggregate nominal exchange rate volatility is likely to translate into higher growth. ${ }^{5}$

Proponents of flexible exchange rate regimes traditionally emphasize the advantage of exchange rate flexibility in the face of real asymmetric shocks (Mundell, 1961, Fischer, 2001). So, when a country is hit by real asymmetric shocks, and prices and wages adjust slowly, flexible exchange rates can adjust relative international prices to compensate for output losses (Mundell, 1961). Another argument in favour of greater exchange rate flexibility is the difference in adjustment to symmetric shocks. Indeed, when a country's response to a common shock differs from that of its trading partners, more independent monetary and exchange rate policies can be needed to support the smooth adjustment of output and/or inflation (Bayoumi and Eichengreen, 1993).

The global financial crisis has renewed the debate about the appropriateness of exchange rate regimes in some CEE countries. Traditionally, the countries with higher exchange rate flexibility are reported to perform better during financial crises (Kaminsky and Reinhart, 1999; Goldstein, Kaminsky and Reinhart, 2000), a finding that also holds for emerging and transition economies (Cerra, Panizza and Saxena, 2009). In contrast, Furceri and Zdzienicka (2009) show that higher exchange rate volatility is associated with higher output loss in the CEE countries.

\footnotetext{
${ }^{5}$ For example, in models that assume investment irreversibility, Bernanke (1983), Pindyck (1991), Pindyck and Solimano (1993) and Price $(1995,1996)$ show that uncertainty and volatility can lead to lower investments, and thus to lower economic growth. Jovanovic (2006) shows pre-commitment to a risky technology determines a negative relation between volatility and growth. More recently, Blackburn and Varvarigos (2005) find that credit constraints and market imperfections can exacerbate uncertainty, leading to lower and more pro-cyclical investments, and thereby to lower growth.
} 
Overall, the impact of exchange rate volatility on growth performance appears to depend significantly on the time period and the sample taken under consideration (Eichengreen and Leblang, 2003).

To assess, the impact of nominal exchange rate volatility on output growth, we estimate the following equation:

$Y_{i t}=\alpha_{i}+\delta X_{i t}+\beta E X_{i t}+\varepsilon_{i t}$

where $Y_{i t}$ is the real GDP growth for country $i$ at time $t$. The vector $\mathrm{X}$ includes a set of control variables affecting growth: i) the ratio of investment to GDP; ii) the fiscal deficit, in per cent of GDP; iii) (the log of) openness; and iv) population growth. We also include v) a dummy for 1998 (Russian crisis) and vi) a dummy for 2008 (the current financial crisis). The choice of these variables is in line with other papers focusing on the effect of exchange rate volatility on economic growth. ${ }^{6}$

We start estimating equation (1) by means of a standard country-fixed effects panel and a robust variance and covariance matrix (Sandwich Estimator). The results are reported in Table 2. Looking at the table it becomes clear that exchange rate volatility has a significant negative impact on growth performance in the CEE economies during the sample period. This effect is robust to the inclusion of different control variables and of time fixed effects.

We tested for possible endogeneity using the Hausman test. The results ${ }^{7}$ confirmed the presence of possible endogeneity for investment and public deficit, but not for exchange rate volatility. ${ }^{8}$ To deal with the presence of endogeneity, we re-estimated equation 2 using the lag of investment and public deficit as instruments. Again, the effect of exchange rate volatility on growth was negative and statistically significant.

\footnotetext{
${ }^{6}$ See, for example, De Grauwe and Schnabl (2005); Schnabl (2007).

${ }^{7}$ The full set of test is availble from the authors upon request.

${ }^{8}$ Also from a theoretical point of view it is difficult to argue that real growth can affect exchange rate volatility.
} 
We also controlled for possible serial correlations and estimated equation (2) by FGLS to deal with the AR (1) structure of the error term. Even in this case, the results were robust.

Finally, following Aghion et al. (2006) we also tested whether the effect of exchange rate volatility on growth in the CEE countries is interrelated with the level of financial development (Hussaim, Mody and Rogoff, 2005) by including the interaction term between exchange rate volatility and the stock of private credit. The results, however, rejected this hypothesis, which may be due to the relative similar degree of financial development among CEE countries.

\subsection{Credit Cycle and Exchange Rate Volatility}

The credit boom in the CEE countries during the last decade has attracted the attention of several researches which aimed to assess whether the increase of credit was excessive (above equilibrium) or a natural process compatible with the catching up process of these economies with the euro area (Cottarelli et al, 2005; Egert et al., 2006; Kiss et al, 2006; Backé et al. 2006; Zdzienicka, 2009). The findings of this stream of literature tended to favour the hypothesis of excessive credit growth, at least in recent years and in some CEE countries. The aim of this section is to assess whether exchange rate volatility could have played a significant role in explaining 'excess' credit development.

From a theoretical point of view, greater exchange rate stability may encourage credit growth by diminishing risk premia and interest rates. As a negative side effect it also increases the possibility that lending growth accelerates to a level no longer justified by fundamentals, thus creating an 'excessive' credit development.

To test for the hypothesis that exchange rate volatility affects excess credit, we follow a two-step approach. First, we estimate the equilibrium level of credit (as a ratio to 
GDP) and compute the deviation of credit from its long term equilibrium. Second, we estimate "excess" credit on exchange rate volatility and other controls variables.

Following a common approach in the literature the credit equilibrium level is estimated using the out-of-sample approach, in which the implied elasticities of long-run credit determinants (GDP per capita and real interest rate ${ }^{9}$ ) are estimated for the 12 Western European countries, which represent the natural benchmark for the CEEs (Cottarelli et al., 2005, Schadler et al, 2005, Egert et al., 2006; Kiss et al., 2006; Zdzienicka, 2009). In detail, to estimate the long-term equilibrium, we apply the pooled mean group (PMG) estimator on the panel of 12 Western European countries over the period 1980-2008. This estimator allows the intercept, short-term coefficients and errors variances to differ from country to country, but the long-term coefficients are constrained to be the same across the group. To determine, the long-term credit equilibrium we also use the constant term of the "benchmark" countries (Maeso-Fernández et al, 2006) ${ }^{10}$.

In the second step we estimate "excess" credit as a function of exchange rate volatility and other controls variables:

$\dot{\tilde{C}}_{l t}=\alpha_{i}+\delta X_{i t}+\beta E X_{i t}+\varepsilon_{i t}$

where the dependent variable is the credit deviation for country $i$ at time $t$ from its longterm equilibrium. The parameter $\beta$ captures the relation between exchange rate volatility and credit deviation. The vector $X$ includes a set of control variables that may affect the deviation of credit from its long-run equilibrium: i) GDP growth, ii) inflation, iii) (the log of the) openness, iv) population growth, v) monetary freedom index and vi) dummies for the announcement of the EU enlargement in 1998 and 2000. The first two variables capture credit expansion that corresponds to its cyclical component at the beginning of a

\footnotetext{
${ }^{9}$ Other variables such as inflation, interest rate spread and public credit were also tested. However, the best specification includes only GDP per capita and interest rate.

${ }^{10}$ All the results are availble from the authors upon request.
} 
cyclical upturn when firms need investment funds (Aghion et al, 1999; IMF, 2004). Openness and population growth capture structural variables (which do not enter in the specification of $\log$ term equilibrium). Monetary freedom and dummies for EU enlargement represent transition-related credit determinants (Arcalean et al, 2005).

We estimate equation (2) using a standard panel country-fixed effect and robust variance and covariance matrix (Sandwich Estimator) ${ }^{11}$. The results, included in Table 3, report a negative and statistically significant impact of exchange rate volatility on credit deviation to its long-term equilibrium ${ }^{12}$. The results are extremely robust to the inclusion of different combination of controls and the inclusion of time fixed effects. Thus, our results confirm our hypothesis and suggest that in countries with less volatile nominal exchange rates the credit-to-GDP ratio can increase above its long-term equilibrium.

\subsection{FDI and exchange rate volatility}

Foreign direct investments have increased strongly in hard-peg and soft peg countries over the last decade. To understand this phenomenon the literature has generally focused on factors such as cost and qualification of labour force, long-term market potential, proximity to natural resources and developed markets business, institutional and legal environment, the degree of financial liberalization.

In contrast the relation between exchange rate volatility and FDI has been mostly ignored $^{13}$. From a theoretical point of view, one could expect that countries with less volatile exchange rates should be more attractive to foreign investors. At the same time, if

\footnotetext{
${ }^{11}$ We also run endogeneity tests, but neither exchange rate volatility nor the control variables turn out to be endogenous to excess credit.

${ }^{12}$ Additionally, we find a positive and generally significant impact of inflation (which can be explained by the fact that high inflation increases uncertainty and thus reduces credit demand, Cottarelli et al. , 2005), monetary freedom (financial and monetary liberalization are positively associated to credit, Kaminsky and Reinhart, 1999) and the dummy for economic integration (credit can overshoot due to "eu-phoria").

${ }^{13}$ Few works inlcude Ricci, (1998); Ito and Kroeger, (2000); Bénassy-Quéré et al., (2001).
} 
foreign investors are not risk-adverse and expect to obtain extra profit exchange rate uncertainty (Darby et al., 1999), exchange rate volatility may have positive impact on FDI.

To test whether exchange rate volatility has a positive or negative effect on FDI we estimate the following equation:

$$
\ln F D I_{i t}=\alpha_{i}+\delta X_{i t}+\beta E X_{i t}+\varepsilon_{i t}
$$

The dependent variable is the (log of the) stock of inward FDI in county $i$ at time $t$. The vector $\mathrm{X}$ includes a set of control variables which are found in the literature to be robust determinants of $\mathrm{FDI}^{14}$ i) (the log of) the level of real GDP; ii) (the log of) the level of real GDP per capita; iii) (the log of) openness, defined as the GDP's share of exports plus imports; iv) openness; v) unit labor costs and vii) dummies for the announcement of EU enlargement in 1998 ("first-wave") and 2000 ("second-wave").

We estimate equation (5) using country-fixed effects and a robust variance and covariance matrix (Sandwich Estimator). The results reported in Table 4 suggest a negative effect of exchange rate volatility on FDI stock. The result is robust across several specifications and the inclusion of time fixed effect. We also test for non-linearity. In fact, it could well be the case that the negative relation between exchange rate volatility and FDI is even more negative for more open economies. For this purpose, we add to our baseline equation the interaction between exchange rate volatility and openness (Interaction). Indeed, the results confirm this hypothesis. The endogeneity between FDI and the independent variables has been tested. The tests confirm the presence of endogeneity with respect to GDP per capita and GDP growth. However, when we reestimate the equation using as instrument the lags of the endogenous variables, the effect of exchange rate volatility is still negative and significant.

\footnotetext{
14 See, for example, Lansbury et al. (1996), Altomonte (1998), Holland and Pain (1998), Resmini (2000), Woodward et al. (2000), Cartensen and Toubal (2003),Clausing and Dorobantu (2005).
} 
Finally, we replicate our estimates using FDI flows (instead of stock) as dependent variables. The results reported in Table 5 still confirm a negative and significant relation between exchange rate volatility and FDI.

\subsection{Current Account and exchange rate volatility}

The widening current account imbalances that have emerged in most CEE countries before the current international financial crisis have attracted considerable attention (see Ca'Zorzi et al., 2009 for a survey). The reason for such development can be found in the size of domestic absorption, in particular a low savings-investment ratio, large capital inflows into the region attracted by investment opportunities and strong economic performance, and large imports of capital good and intermediate factors.

From a theoretical point of view, a country that runs a substantial current account deficit should generate a trade balance surplus through an increase in competitiveness by real exchange rate depreciation (Roubini and Watchel, 1998, Chinn and Wei, 2008). ${ }^{15}$ Based on this, the fact that CEE countries with more flexible exchange rate show experienced smaller current account disequilibria is a priori justified. At the same time, the sign of the impact of exchange rate volatility depends on the impact of exchange rate volatility on saving and investment. As argued before, higher exchange rate volatility may decrease investment (especially foreign ones) due to higher risk premia and interest rate. On the other side, exchange rate volatility has an impact of consumption and saving decisions because it amplifies or reduces macroeconomic volatility and consumption smoothing. Thus, the impact of exchange rate volatility on the current account balance is not certain a priori and depends on the sign and the magnitude of the effect of exchange rate volatility on saving and investment.

\footnotetext{
${ }^{15}$ The risk of real appreciation is even more important in transition economies where the catchin-up process results in higher inflation (Balassa-Samuelson effect, administrative prices and taxes adjustment; Schadler et al., 2005).
} 
Also from an empirical point of view there is a lack of consensus on the effect of exchange rate volatility on current account imbalances. While some authors have found a positive and robust relation between current account adjustment and exchange rate flexibility (Rahman, 2008; Herrman, 2009; Gosh et al. 2009), other studies have found the absence of any significant relation (Chinn and Wei, 2008; Slavov, 2009).

In order to test for a significant relation between exchange rate volatility and the current account balance, we estimate the following equation:

$$
\frac{C A}{Y} i t=\alpha_{i}+\delta X_{i t}+\beta E X_{i t}+\varepsilon_{i t}
$$

where the dependent variable is the ratio of the current account balance to GDP for country $i$ at time $t$. The vector $\mathrm{X}$ includes a set of control variables affecting saving and investment. In particular, following the literature on the determinants of current account balance $^{16}$, we include the following variables: i) relative income (to the EU15); ii) relative income squared; iii) GDP growth ); iii) FDI inflow; iv) Inflation; v) credit-to-GDP (financial deepening); vi) public deficit; vii) Openness viii) and capital controls.

The estimates of equation (5) are reported in Table 6 . The results suggest a positive and statistically significant relation between exchange rate volatility and current account balance. The results are extremely robust to different inclusion of controls, time fixed effects and the AR(1) structure of the error term. Given the (tested) endogeneity of GDP growth, FDI and the public deficit to the current account, we also estimated the relation using IV, instrumenting these variables with their lags. The results confirm the significant relation between nominal exchange rate volatility and the current account balance.

\footnotetext{
16 See, for example,Chinn and Prasad (2003); Chinn and Ito (2007, 2008), Gruber and Kamin (2007, 2009) for a detailed discussiion of the detemriants of current account imbalances.
} 
In all, the results suggest that countries with higher exchange rate volatility have more balanced current accounts, which reflects the impact of exchange rate volatility on saving and investment.

\section{Conclusions}

Exchange rate strategies in the CEE countries differ considerably, from fixed exchange rate regimes to pure floaters. At the beginning of the transition process, most CEE countries relied on pegging the exchange rate to a highly stable currency, such as the US dollar or the Deutsche Mark, as a way to import credibility from abroad and reduce inflation. In the course of the 1990s, a number of countries gradually softened their peg and moved towards more monetary policy autonomy and several countries adopted inflation targeting as a monetary policy framework.

When we look at stylized facts regarding the macroeconomic performance of the "hard peg" and "floating" CEE country groups over the period 1995-2008, the evidence is quite mixed. While "hard-pegs" tended to experience faster real GDP and credit growth than "floaters", they also tended to experience relatively larger external imbalances and a more significant adjustment process since the beginning of the current international financial crisis.

Moving beyond stylized facts, the empirical results of our paper suggest that differences in exchange rate volatility across the CEE countries during the 1995-2008 period are, indeed, associated with differences in key macroeconomic variables. More specifically, our findings suggest that, over this period as a whole, lower nominal exchange rate volatility was associated with higher growth, higher stocks of FDI, higher current account deficits, and higher excess credit. 


\section{References}

Aizenman J. (1992), "Exchange Rate Flexibility, Volatility and the Patterns of Domestic and Foreign Direct Investment", NBER Working Paper 3953.

Aghion, P., P. Bachetta, R. Ranciere and K. Rogoff (2006), "Productivity Growth and the Exchange Rate Regime: the Role of Financial Development", NBER Working Paper 12117.

Altomonte, C. (1998), "FDI in the CEECs and the theory of real options: An empirical assessment", LICOS Discussion Paper 76, Katholieke Universiteit Leuven, Belgium.

Atkeson, A. and M. Ogaki (1991), "Does the Intertemporal Elasticity of Substitution Vary with Wealth and does that Matter for Aggregate Savings?", University of Rochester, mimeo.

Baxter M. and A.Stockman (1989), "Business Cycles and the Exchange-Rate Regimes", Journal of Monetary Economics 23(3), 377-400.

Bayoumi T. and B. Eichengreen (1993), "Shocking Aspects of European Monetary Integration", in F. Torres and F. Giavazzi (eds.), "Growth and Adjustment in the European Monetary Union”, Cambridge University Press, Oxford, 1993, 193-230.

Bénassy-Quéré A., Fontagne L.G. and A. Lahreche-Revil (2001), "Exchange Rate Strategies in the Competition for Attracting FDI", Journal of the Japanese and International Economies 15, 178-198.

Bernanke, B. S. (1983) Irreversibility, uncertainty and cyclical investments, Quarterly Journal of Economics, 23, 85-106.

Blackburn, K. and Varvarigos, D. (2005) Growth, uncertainty and finance, Centre for Growth and Business Cycle Research Discussion Papers, 48, 1-24.

Brzozowski, M. (2006), "Exchange Rate Variability and Foreign Direct Investment Consequences of EMU Enlargement", Eastern European Economics 44(1), 5-24.

Calvo, G. and C. Reinhart (2002), "Fear of Floating," Quarterly Journal of Economics $117,2,379-408$.

Carstensen, K. and F. Toubal (2003), 'Foreign direct investment in Central and Eastern European countries: A dynamic panel analysis', Kiel Institute for World Economics Working Paper No. 1143, Germany: Kiel.

Ca'Zorzi M., A. Chudik and A. Dieppe (2009), "Current Account Benchmarks for Central and Eastern Europe. A Desperate Search?”, ECB Working Paper, No. 995.

Cerra, V, U. Panizza and S.C. Saxena (2009), "International Evidence on Recovery from Recessions", IMF Working Paper, No. 09/183.

Clausing, K. and C. Dorobantu (2005), "Re-entering Europe: Does European Union Candidacy Boost Foreign direct Investment?," Economics of Transition, 13,1, 77-103.

Chang, R. and A. Velasco (1998), "The Asian Liquidity Crisis", NBER Working Paper, No 6796.

Chang, R. and A. Velasco (2000), "Financial Fragility and the Exchange Rate Regime", Journal of Economic Theory, vol. 92(1), 1-34. 
Chinn, M. and E. Prasad, (2003). "Medium-term determinants of current accounts in industrial and developing countries: an empirical exploration," Journal of International Economics, 59(1), 47-76.

Chinn, M. and H. Ito (2007). "Current account balances, financial development and institutions: Assaying the world "saving glut"," Journal of International Money and Finance, 26(4), 546-569.

Chinn, M. and H. Ito (2008). "Global Current Account Imbalances: American Fiscal Policy versus East Asian Savings," Review of International Economics, 16(3), 479-498.

Chinn, M. and S.-J. Wei (2008), “A Faith-based Initiative: Does a Flexible Exchange Rate Regime Really Facilitate Current Account Adjustment?”, NBER Working Paper 14420.

Cottarelli, C., G. Dell'Ariccia and I. Vladkova-Hollar (2005), "Early birds, late risers and sleeping beauties: Bank credit growth to the private sector in Central and Eastern Europe and in the Balkans", Journal of Banking and Finance. 29, 83-104.

Darby, J., A.H. Hughes Hallett, J.Ireland and L. Piscitelli (1999), "The Impact of Exchange Rate Uncertainty on the Level of Investment", The Economic Journal 105, 5567.

De Grauwe P. (2005), Economics of Monetary Union (Oxford University Press).

De Grauwe, P. and G. Schnabl (2005), "Exchange Rate Regime and Macroeconomic Performance in Central and Eastern Europe", CESifo Working Paper 1182.

Dornbusch, R. (2001), "Fewer Monies, Better Monies", American Economic Review, May, 238-242.

Edwards, S. and E. Levy-Yeyati (2003), "Flexible Exchange Rates as Shock Absorbers," NBER Working Paper.

Egert, B., P. Backé and T. Zumer (2006), "Credit Growth in Central and Eastern Europe: New Overshooting Stars?”, ECB Working Papers, 687.

Eichengreen, B. and D. Leblang (2003), "Exchange Rates and Cohesion: Historical Perspectives and Political-Economy Considerations," Journal of Common Market Studies 41, 797-822.

Fischer, Stanley (2001), "Exchange Rate Regimes: Is the Bipolar View Correct?" Journal of Economic Perspectives 15, 2, 3-24.

Frankel, J. and A. Rose (2002), "An Estimate of the Effect of Common Currencies on Trade and Income," Quarterly Journal of Economics 117, 437-66.

Frenkel , M., K. Funke and G. Stadtmann (2004), "A Panel Analysis of Bilateral FDI Flows to Emerging Economies", Economic Systems 28, 281-300

Furceri, D. and A. Zdzienicka (2009) “The Real Effect of Financial Crises in the European Transition Economies", GATE Working Paper 20.

Giovannini, A. (1985), "Saving and Real Interest Rate", Journal of Development Economics, Vol. 18, 197-217.

Ghosh, A., A-M Gulde, and H. Wolf (2003), Exchange Rate Regimes: Choices and Consequences (Cambridge, Massachusetts: MIT Press). 
Ghosh, A., M. Terrones and J. Zellelmeyer (2009), "Exchange Rate Regimes and External Adjustment: New Ansers to an Old Debate" at http://www.iheid.ch/webdav/site/ international_economics /shared/international_economics/events/Swoboda/ZettelemeyerERRs\%20and\%20external\%20adjustment\%203-1.pdf

Goldstein, M., G.L. Kaminsky and C.M. Reinhart (2000), "Assessing Financial Vulnerability: An Early Warning System for Emerging Markets", Washington: Institute for International Economics

Gruber, J.W., Kamin, S.B. (2007), "Explaining the Global Pattern of Current Account Imbalances," Journal of International Money and Finance, 26, 500-522.

Gruber, J.W., Kamin, S.B. (2009) "Do Differences in Financial Development Explain the Global Pattern of Current Account Imbalances?," Review of International Economics, 17(4), 667-688.

Gourinchas, P.-O., O. Landerretche and R. Valdés (2001), "Lending Booms: Latin America and the World," CEPR Discussion Papers 2811.

Herrmann S. (2009), "Do We Really Know That Flexible Exchange Rate Facilitate Current Account Adjustment? Some New Empirical Evidence for CEE Economies", Deutsche Bundesbank Discussion Paper 22/2009.

Holland, D. and N. Pain (1998), 'The diffusion of innovations in Central and Eastern Europe: A study of the determinants and impact of foreign direct investment', National Institute of Economic and Social Research Working Paper No. 137, London: NIESR.

Hussain A.M., A.Mody and K.S. Rogoff (2005), "Exchange Rate Regimes Durability and Performance in Developing versus Advances Economies", Journal of Monetary Economics 52, 35-64.

International Monetary Fund (various issues), Annual Report on Exchange Rate Arrangements and Exchange Restrictions (Washington).

Ito T and A.O. Krueger (2000), "The Role of Foreign Direct Investment in East Asian Economic Development” (NBER, the Chicago University Press, Chicago).

Jovanovic, B. (2006) Asymmetric cycles, Review of Economic Studies, 73, 145-62.

Kaminsky G. and C. Reinhart (1999), "The Twin Crises. The Causes of Banking and Balance-of-Payments Problems," American Economic Review, vol. 89(3), 473-500.

Kiss, G. and G. Vadas (2005), "The role of the housing market in monetary transmission", National Bank of Hungary, Background Study 3.

Kiss, G. Nagy, M. and B. Vonnák (2006), "Credit Growth and Eastern Europe: Trend, Cycle and Boom?", mimeo.

Lansbury, M., N. Pain and K. Smidkova (1996), 'Foreign direct investment in Central Europe since 1990: An econometric study', National Institute Economic Review, 156, 104-13.

Maeso-Fernandez F., C. Osbat and B. Schnatz (2004), "Towards the Estimation of Equilibrium Exchange Rates for CEE Acceding Countries: Methodological Issues and a Panel Cointegration Perspective", ECB Working Paper, No. 353

McKinnon, R. and G. Schnabl (2004), "The East Asian Dollar Standard, Fear of Floating, and Original Sin," Review of Development Economics 8, 3, 331-60. 
Meade, James (1951), The Theory of International Economic Policy (London: Oxford University Press).

Mundell R.A. (1961), “A Theory of Optimum Currency Areas", American Economic Review 51, 657-665.

Pindyck, R. S. (1991) Irreversibility, uncertainty and investments, Journal of Monetary Economics, 12,139-62.

Pindyck, R. S. and Solimano, A. (1993) Economic instability and aggregate investments, in NBER Macroeconomics Annual (Eds) O. J. Blanchard and S. Fisher, (The MIT Press, Cambridge).

Price, S. (1995) Aggregate uncertainty, capacity utilization and manufacturing investment, Applied Economics, 27, 147-54.

Price, S. (1996) Aggregate uncertainty, investment and asymmetric adjustment in the UK manufacturing sector, Applied Economics, 28, 1369-79.

Rahman J. (2008), "Current Account Developments in New Member States of the European Union: Equilibrium, Excess and EU-Phoria", IMF Working Paper 92.

Rebelo, S. (1992), "Growth in Open Economies”, Discussion Paper, No. 667, CEPR.

Ravn, M. O. and H. Uhlig (2002), "On Adjusting the Hodrick-Prescott Filter for the Frequency of Observations", Review of Economics and Statistics 84(2), 371-380.

Resmini, L. (2000), "The determinants of foreign direct investment in the CEECs: New evidence from sectoral patterns", Economics of Transition, 8(3), pp. 665-89.

Ricci L.A. (1998), "Uncertainty, Flexible Exchange Rate, and Agglomeration", IMF Working Paper 9.

Rose, A.K. (2000), "One Money, One Market: Estimating the Effect of Common Currencies on Trade", Economic Policy, 30, 7-46.

Roubini N. and P. Wachtel (1998), "Current Account Sustainability in Transition Economies", NBER Working Paper, No. 6468.

Schnabl, Gunther (2007). "Exchange Rate Volatility and Growth in Small Open Economies at the EMU Periphery", ECB Working Paper, No. 773

Selhattini, D. (1997), “Accounting for US Current Account Deficits: an Empirical Investigation", Applied Economics, No. 29.

Slavov S. T. (2009), "Structural Current Account Imbalances: Fixed versus Flexible Exchange Rates? at http://www.economics.pomona.edu/slavov/regimes.pdf

Woodward, D.-P., R.-J. Rolfe, P. Guimarães and T. Doupnik (2000), "Taxation and the location of foreign direct investment in central Europe", in Fatemi, K. (ed.), The New World Order: Internationalism and the Multinational Corporations, Pergamon Press (Elsevier Science) 46, 192-203.

Zdzienicka A. (2008), "Financial Vulnerabilities in Central and Eastern Europe: Credit Growth", GATE Working Paper, No.09/12. 
Figure 1. Real GDP Growth (in \%)

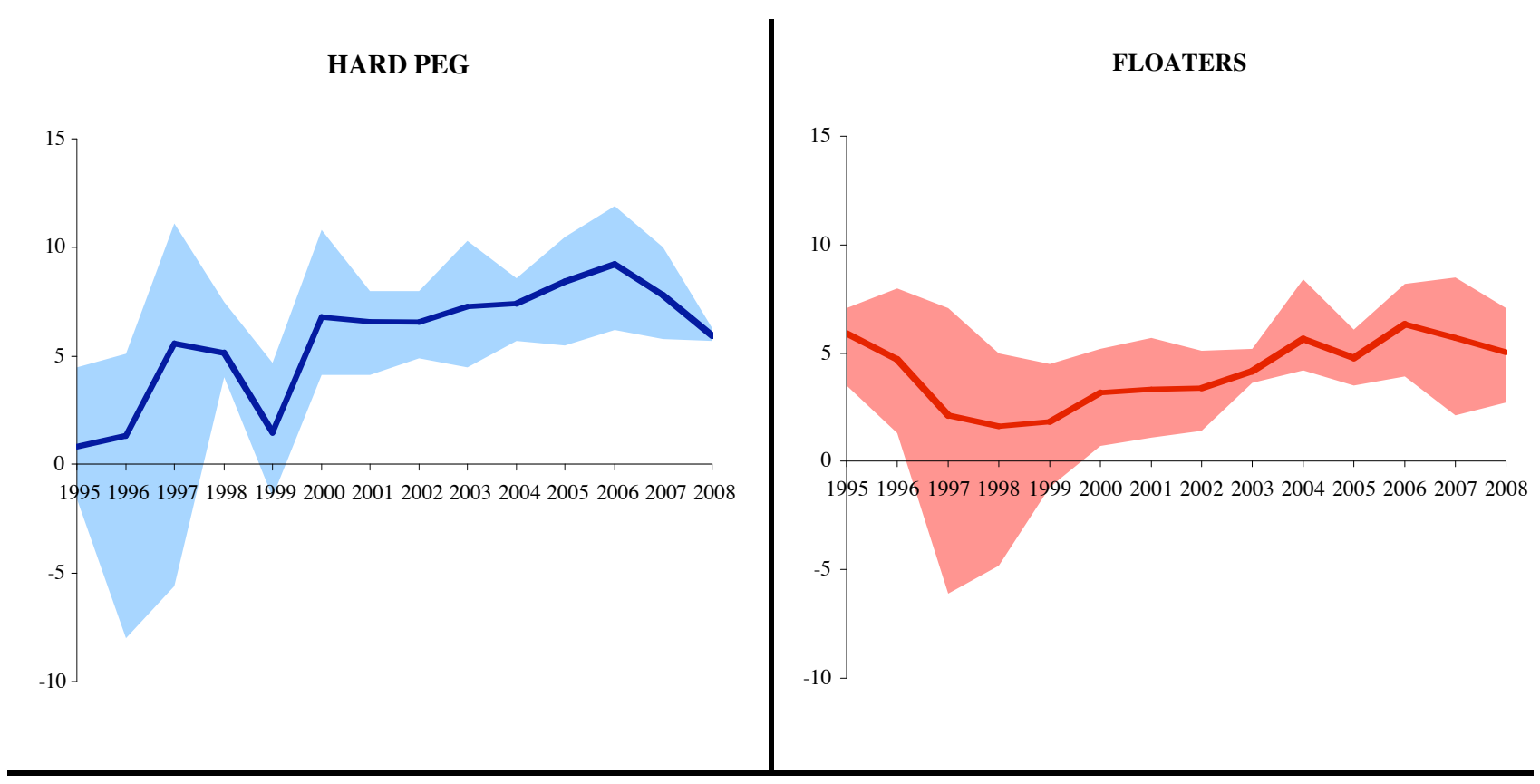

Source: Eurostat. Shaded area corresponds to maximum and minimum values, Lines to un-weighted average.

Figure 2. Credit-to-GDP Growth (in \%)

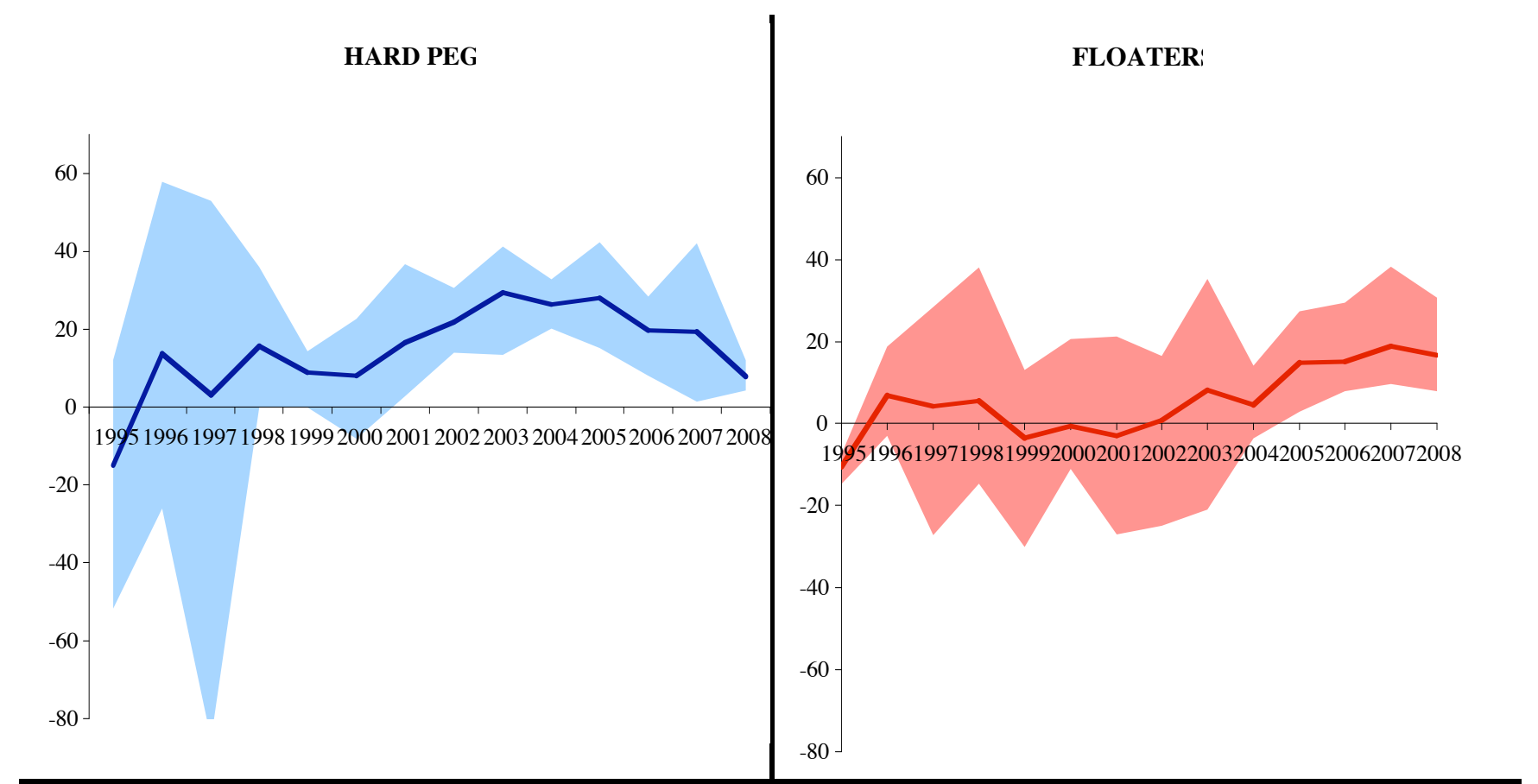

Source: Eurostat. Shaded area corresponds to maximum and minimum values, Lines to un-weighted average. 
Figure 3. FDI Inflow (Real terms, $\log$ of Millions of \$)

HARD PEGr

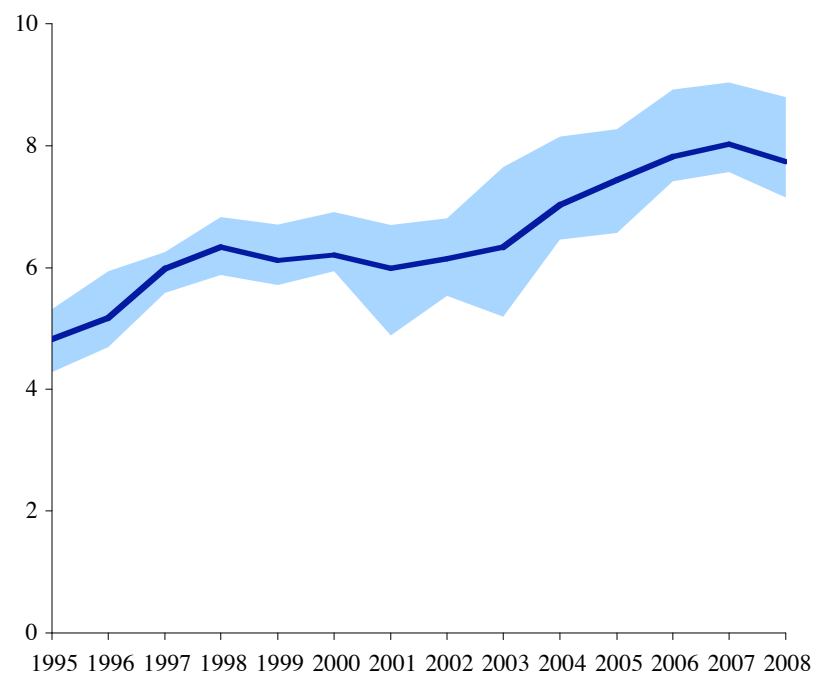

FLOATERS

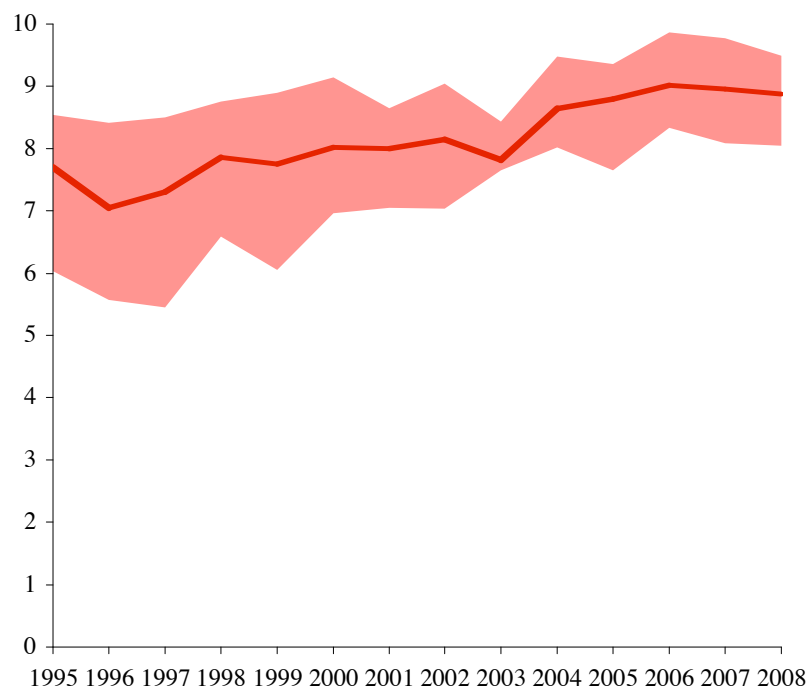

Source: UNCTADD. Shaded area corresponds to maximum and minimum values, Lines to un-weighted average

Figure 4. FDI Stock Inward (Real terms, log of Millions of \$)

HARD PEGS

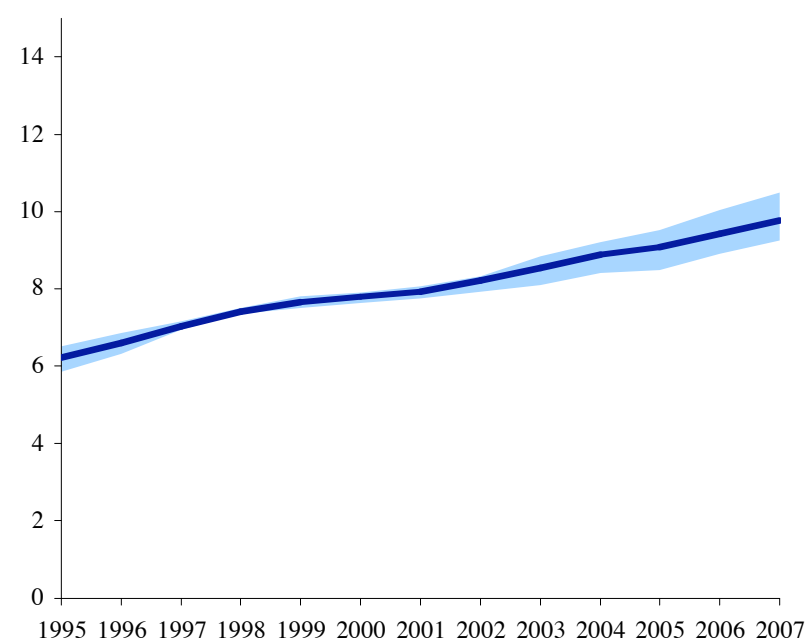

FLOATERS

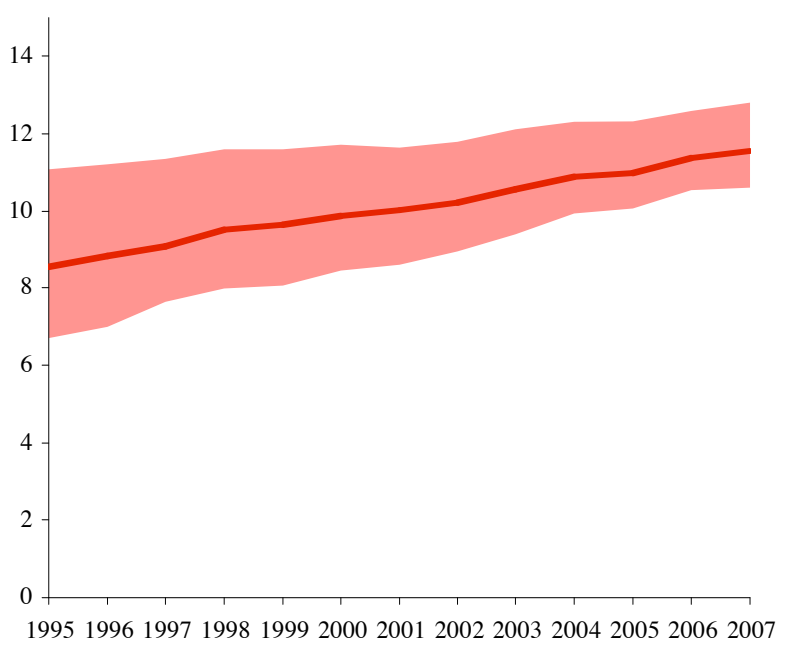

Source: UNCTADD. Shaded area corresponds to maximum and minimum values, Lines to un-weighted average. 
Figure 5. Current account balance (\% of GDP)

HARD PEG

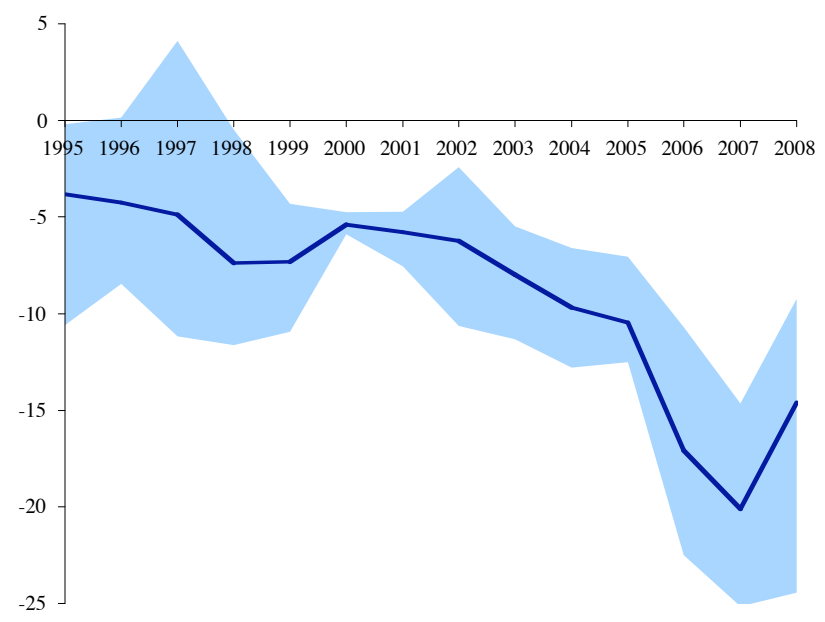

FLOATERS

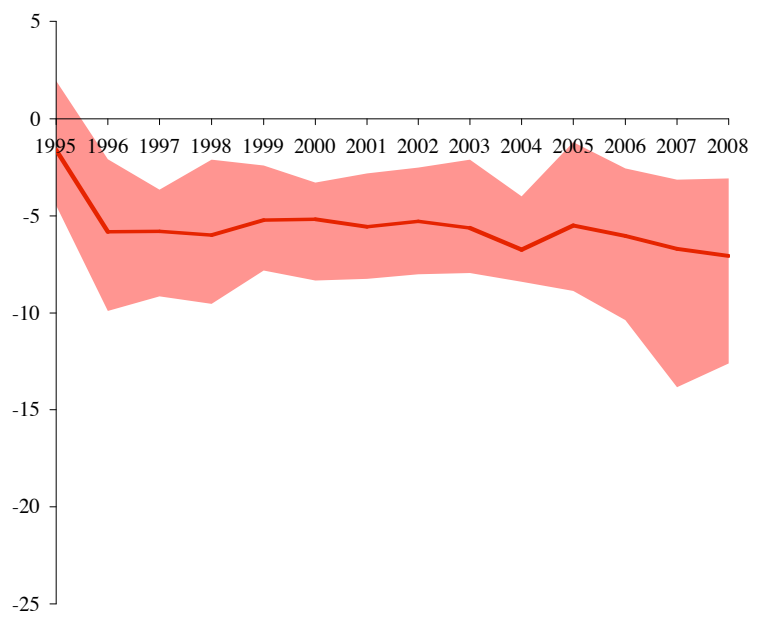

Source: Eurostat. Shaded area corresponds to maximum and minimum values, Lines to un-weighted average

Table 1. Official monetary policy strategies of CEE countries up to 2008

\begin{tabular}{|c|c|c|c|}
\hline \multicolumn{4}{|c|}{ Official monetary policy strategies of Central and Eastern European EU Member States } \\
\hline & Monetary policy strategy & Currency & Features \\
\hline Bulgaria & Exchange rate target & Bulgarian lev & $\begin{array}{l}\text { Exchange rate target: peg to the euro at } 1.95583 \text { lev per } \\
\text { euro within the framework of a currency board } \\
\text { arrangement. }\end{array}$ \\
\hline Czech Republic & Inflation target & Czech koruna & $\begin{array}{l}\text { Target: } 3 \% \pm 1 \text { percentage point until end- } 2009 \text {; thereafter } \\
2 \% \pm 1 \text { percentage point. Managed floating exchange rate. }\end{array}$ \\
\hline Estonia & Exchange rate target & Estonian kroon & $\begin{array}{l}\text { Participates in ERM II with a } \pm 15 \% \text { fluctuation band } \\
\text { around central rate of EEK } 15.6466 \text { per euro. Estonia } \\
\text { continues with its currency board arrangement as a } \\
\text { unilateral commitment. }\end{array}$ \\
\hline Latvia & Exchange rate target & Latvian lats & $\begin{array}{l}\text { Participates in ERM II with a } \pm 15 \% \text { fluctuation band } \\
\text { around central rate of LVL } 0.702804 \text { per euro. Latvia } \\
\text { continues with a fluctuation band of } \pm 1 \% \text { as a unilateral } \\
\text { commitment. }\end{array}$ \\
\hline Hungary & Inflation target & Hungarian forint & $\begin{array}{l}\text { Inflation target: } 3 \% \text { ( } \pm 1 \text { p.p.) medium term target since } \\
2007 \text {. }\end{array}$ \\
\hline Poland & Inflation target & Polish zloty & $\begin{array}{l}\text { Inflation target: } 2.5 \% \text {, with } \pm 1 \text { percentage point (12- } \\
\text { month increase in the CPI). Free floating exchange rate. }\end{array}$ \\
\hline Romania & Inflation target & Romanian leu & $\begin{array}{l}\text { Inflation target: } 4 \%, 3.8 \% \text { and } 3.5 \% \text {, with } \pm 1 \text { percentage } \\
\text { point for end-2007, } 2008 \text { and } 2009 \text {, respectively. Managed } \\
\text { floating exchange rate. }\end{array}$ \\
\hline
\end{tabular}


Table 1: Output Growth and Exchange Rate Volatility

\begin{tabular}{|c|c|c|c|c|c|c|c|c|c|c|}
\hline & $\mathrm{OLS}+\mathrm{FE}$ & $\mathrm{OLS}+\mathrm{FE}$ & $\mathrm{OLS}+\mathrm{FE}$ & $\mathrm{OLS}+\mathrm{FE}$ & $\mathrm{OLS}+\mathrm{FE}$ & $\mathrm{OLS}+\mathrm{FE}$ & $\mathrm{OLS}+\mathrm{FE}$ & $\begin{array}{c}\mathrm{OLS}+\mathrm{FE}+ \\
\text { time FE }\end{array}$ & $2 \mathrm{SLS}^{\#}$ & $\operatorname{AR}(1)$ \\
\hline \multirow{3}{*}{ Zscore } & -0.001 & -0.001 & -0.001 & -0.001 & -0.001 & -0.001 & -0.001 & -0.001 & 0.001 & -0.001 \\
\hline & $(-4.40) * * *$ & $(-4.88) * * *$ & $(-3.22) * * *$ & $(-6.21) * * *$ & $(-6.30)^{* * *}$ & $(-7.27) * * *$ & $(-7.98) * * *$ & $(-7.49) * * *$ & $(-4.48) * * *$ & $(-4.24) * * *$ \\
\hline & 0.495 & & 0.160 & 0.078 & 0.132 & 0.214 & 0.197 & 0.204 & -0.077 & -0.014 \\
\hline \multirow[t]{2}{*}{ Investment } & $(0.93)$ & & $(2.92) * * *$ & $(1.50)$ & $(2.11) * *$ & $(3.00) * * *$ & $(3.28) * * *$ & $(3.41)^{* * *}$ & $(-1.16)$ & $(0.88)$ \\
\hline & 0.005 & 0.006 & & 0.006 & 0.006 & 0.006 & 0.005 & 0.004 & 0.007 & 0.005 \\
\hline \multirow[t]{2}{*}{ Deficit } & $(5.17) * * *$ & $(5.30) * * *$ & & $(4.56) * * *$ & $(6.28) * * *$ & $(4.86) * * *$ & $(4.53) * * *$ & $(4.17)^{* * *}$ & $(2.85)^{* * *}$ & $(3.49) * * *$ \\
\hline & 0.064 & 0.068 & 0.079 & & 0.056 & 0.061 & 0.758 & 0.041 & 0.060 & 0.087 \\
\hline Openness & $(4.50) * * *$ & $(3.87)^{* * *}$ & $(3.97) * * *$ & & $(3.58) * * *$ & $(3.80) * * *$ & $(4.31)^{* * *}$ & $(1.63)^{*}$ & $(3.94) * * *$ & $(3.92) * * *$ \\
\hline Population & 0.020 & 0.023 & 0.029 & 0.226 & & & 0.027 & 0.022 & 0.026 & 0.014 \\
\hline \multirow[t]{2}{*}{ growth } & $(2.07)^{* *}$ & $(2.10)^{* *}$ & $(2.52)^{* *}$ & $(2.11)^{* *}$ & & & $(2.98) * * *$ & $(2.63) * * *$ & $(2.54)^{* *}$ & $(0.88)$ \\
\hline & & -0.009 & -0.149 & -0.018 & -0.014 & -0.016 & -0.013 & -0.025 & -0.003 & \\
\hline \multirow[t]{2}{*}{ Dummy_1998 } & & $(-1.01)$ & $(-0.98)$ & $(-1.81)^{*}$ & $(-1.47)$ & $(-1.78)^{*}$ & $(-1.51)$ & $(-2.34) * *$ & $(-0.47)$ & \\
\hline & & -0.011 & -0.015 & -0.110 & -0.016 & -0.013 & -0.013 & -0.011 & -0.007 & \\
\hline Dummy_2008 & & $(-2.74) * * *$ & $(-2.78) * * *$ & $(-1.81)^{*}$ & $(-2.75) * * *$ & $\begin{array}{l}(-2.59)^{* *} \\
-0.000\end{array}$ & $(-3.12) * * *$ & $(-1.00)$ & $(-2.16) * *$ & \\
\hline Credit & & & & & & $(-2.33) * *$ & & & & \\
\hline & & & & & & -0.000 & & & & \\
\hline Interaction & & & & & & $(-0.89)$ & & & & \\
\hline Observations & 115 & 117 & 115 & 115 & 123 & 123 & 115 & 115 & 114 & 106 \\
\hline $\mathrm{R}^{2}$ & 0.69 & 0.70 & 0.63 & 0.66 & 0.67 & 0.69 & 0.75 & 0.80 & 0.69 & $0.40^{\# \#}$ \\
\hline
\end{tabular}

Robust standard errors; t-statistics in parentheses

$*, * *, * *$ respectively significant at $10 \%, 5 \%$ and $1 \% ;{ }^{\#}$ Instrumented variables: Investment, Deficit, ${ }^{\# \#} \mathrm{R}^{2}$ within,

Table 2: Credit Deviations and Exchange Rate Volatility

\begin{tabular}{|c|c|c|c|c|c|c|c|}
\hline & $\mathrm{OLS}+\mathrm{FE}$ & $\mathrm{OLS}+\mathrm{FE}$ & $\mathrm{OLS}+\mathrm{FE}$ & $\mathrm{OLS}+\mathrm{FE}$ & $\mathrm{OLS}+\mathrm{FE}$ & $\mathrm{OLS}+\mathrm{FE}$ & $\begin{array}{c}\text { OLS +FE+ } \\
\text { time FE }\end{array}$ \\
\hline Zscore & $\begin{array}{l}-6.334 \\
(-2.57)^{* *}\end{array}$ & $\begin{array}{l}-6.228 \\
(-3.03) * * *\end{array}$ & $\begin{array}{l}-0.404 \\
(-1.78)^{*} \\
-89.321\end{array}$ & $\begin{array}{l}-6.559 \\
(- \\
3.06)^{* * * *}\end{array}$ & $\begin{array}{l}-6.191 \\
(-3.01)^{* * *}\end{array}$ & $\begin{array}{l}-3.142 \\
(-1.71)^{*}\end{array}$ & $\begin{array}{l}-5.055 \\
(-2.83)^{* * *}\end{array}$ \\
\hline GDPgrowth & $\begin{array}{l}-75.013 \\
(-0.91)\end{array}$ & & $(-1.09)$ & $\begin{array}{l}31.611 \\
(0.41)\end{array}$ & $\begin{array}{l}-25.217 \\
(-0.37)\end{array}$ & $\begin{array}{l}-17.465 \\
(-0.23)\end{array}$ & $\begin{array}{l}-109.926 \\
(-1.24)\end{array}$ \\
\hline Inflation & $\begin{array}{c}0.950 \\
(2.43)^{* * *}\end{array}$ & $\begin{array}{c}0.947 \\
(2.87)^{* * *}\end{array}$ & & $\begin{array}{c}1.007 \\
(2.94)^{* * *}\end{array}$ & $\begin{array}{c}0.936 \\
(2.85)^{* * *}\end{array}$ & $\begin{array}{l}0.429 \\
(1.48)\end{array}$ & $\begin{array}{c}0.726 \\
(2.54)^{* *}\end{array}$ \\
\hline Openness & $\begin{array}{l}16.000 \\
(1.07)\end{array}$ & $\begin{array}{l}-5.441 \\
(-0.39)\end{array}$ & $\begin{array}{l}12.030 \\
(0.85)\end{array}$ & $\begin{array}{l}-9.399 \\
(-0.63)\end{array}$ & & $\begin{array}{l}17.013 \\
(1.17)\end{array}$ & $\begin{array}{l}-60.179 \\
(-2.84) * * *\end{array}$ \\
\hline $\begin{array}{l}\text { Population } \\
\text { growth }\end{array}$ & $\begin{array}{l}26.981 \\
(2.15)^{* *}\end{array}$ & $\begin{array}{l}19.491 \\
(1.85)^{*}\end{array}$ & $\begin{array}{l}23.865 \\
(2.04)^{* *}\end{array}$ & & $\begin{array}{l}20.391 \\
(1.95)^{*}\end{array}$ & $\begin{array}{l}34.016 \\
(3.38)^{* * *}\end{array}$ & $\begin{array}{l}11.372 \\
(1.36)\end{array}$ \\
\hline Monetary & 0.516 & 0.530 & 0.199 & 0.672 & 0.517 & & 0.421 \\
\hline Freedom & $(4.00)^{* * *}$ & & $\begin{array}{l}(1.66)^{*} \\
-3.391\end{array}$ & & & -2.605 & $(2.57)^{* *}$ \\
\hline $\begin{array}{l}\text { Dummy_1998 } \\
\text { Dummy_2000 }\end{array}$ & & $\begin{array}{l}(-0.02) \\
25.892 \\
(3.76)^{* * *}\end{array}$ & $\begin{array}{l}(-0.63) \\
24.892 \\
(3.03)^{* * *}\end{array}$ & $\begin{array}{l}(-0.10) \\
27.720 \\
(3.84)^{* * *}\end{array}$ & $\begin{array}{l}(0.01) \\
25.304 \\
(3.81)^{* * *}\end{array}$ & $\begin{array}{l}(-0.42) \\
25.259 \\
(3.11)^{* * *}\end{array}$ & \\
\hline Observations & 109 & 109 & 115 & 109 & 109 & 111 & 109 \\
\hline $\mathrm{R}^{2}$ & 0.48 & 0.58 & 0.50 & 0.55 & 0.58 & 0.52 & 0.72 \\
\hline
\end{tabular}

Robust standard errors; $t$-statistics in parentheses

$*, * *, * * *$ respectively significant at $10 \%, 5 \%$ and $1 \%$; 
Table 3: FDI stock and Exchange Rate Volatility

\begin{tabular}{|c|c|c|c|c|c|c|c|c|c|}
\hline & $\mathrm{OLS}+\mathrm{FE}$ & $\mathrm{OLS}+\mathrm{FE}$ & $\mathrm{OLS}+\mathrm{FE}$ & $\mathrm{OLS}+\mathrm{FE}$ & $\mathrm{OLS}+\mathrm{FE}$ & $\mathrm{OLS}+\mathrm{FE}$ & $\mathrm{OLS}+\mathrm{FE}$ & $\begin{array}{c}\text { OLS } \\
+\mathrm{FE}+ \\
\text { time FE }\end{array}$ & 2SLS\# \\
\hline Zscore & $\begin{array}{l}-0.005 \\
(-3.29) * * *\end{array}$ & $\begin{array}{c}-0.005 \\
(-3.09)^{* * *}\end{array}$ & $\begin{array}{l}-0.005 \\
(-2.44)^{* * *}\end{array}$ & $\begin{array}{c}-0.006 \\
(-2.97) * * *\end{array}$ & $\begin{array}{c}-0.005 \\
(-3.51)^{* * *}\end{array}$ & $\begin{array}{c}-0.005 \\
(-3.34)^{* * *}\end{array}$ & $\begin{array}{c}-0.006 \\
(-3.90)^{* * *}\end{array}$ & $\begin{array}{c}-0.006 \\
(-2.92)^{*}\end{array}$ & $\begin{array}{c}-0.007 \\
(-1.79)^{*}\end{array}$ \\
\hline GDP & $\begin{array}{l}-0.301 \\
(-0.83)\end{array}$ & & $\begin{array}{l}-0.711 \\
(-1.90)^{* *}\end{array}$ & $\begin{array}{c}0.500 \\
(13.81)^{* * *}\end{array}$ & $\begin{array}{l}-0.020 \\
(-0.05)\end{array}$ & $\begin{array}{c}-0.516 \\
(-1.96)^{*}\end{array}$ & $\begin{array}{l}-0.466 \\
(-1.42)\end{array}$ & $\begin{array}{l}0.466 \\
(1.28)\end{array}$ & $\begin{array}{l}-0.011 \\
(-0.03)\end{array}$ \\
\hline GDP_capita & $\begin{array}{l}0.014 \\
(3.15)^{* * *}\end{array}$ & $\begin{array}{c}0.015 \\
(4.02)^{* * *}\end{array}$ & & $\begin{array}{c}0.018 \\
(4.54)^{* * *}\end{array}$ & $\begin{array}{c}0.026 \\
(6.34)^{* * *}\end{array}$ & $\begin{array}{c}0.018 \\
(9.92)^{* * *}\end{array}$ & $\begin{array}{c}0.018 \\
(9.82)^{* * *}\end{array}$ & $\begin{array}{c}-0.003 \\
(-0.79)^{* * *}\end{array}$ & $\begin{array}{c}0.018 \\
(8.56)^{* * *}\end{array}$ \\
\hline Openness & $\begin{array}{l}0.746 \\
(4.48)^{* *}\end{array}$ & $\begin{array}{c}0.477 \\
(11.86)^{* * *}\end{array}$ & $\begin{array}{l}1.202 \\
(3.33)^{* * *}\end{array}$ & & $\begin{array}{l}0.460 \\
(1.27)\end{array}$ & $\begin{array}{c}0.934 \\
(3.17)^{* * *} \\
0.000 \\
(-2.14)^{* *}\end{array}$ & $\begin{array}{c}0.885 \\
(2.79)^{* * *}\end{array}$ & $\begin{array}{l}-0.211 \\
(-0.60)\end{array}$ & $\begin{array}{l}0.490 \\
(1.26)\end{array}$ \\
\hline $\begin{array}{l}\text { Financial } \\
\text { Freedom } \\
\text { Labor Unit } \\
\text { Cost }\end{array}$ & $\begin{array}{l}0.168 \\
(4.48)^{* * *} \\
0.005 \\
(0.81)\end{array}$ & $\begin{array}{c}0.016 \\
(4.54) * * * \\
0.003 \\
(0.63)\end{array}$ & $\begin{array}{l}0.023 \\
(7.09)^{* * *} \\
0.019 \\
(6.78)^{* * *}\end{array}$ & $\begin{array}{c}0.016 \\
\left(4.42^{\circ} * * *\right. \\
0.002 \\
(0.28)\end{array}$ & $\begin{array}{l}-0.004 \\
(-0.61)\end{array}$ & $\begin{array}{c}0.014 \\
(4.06)^{* * *}\end{array}$ & $\begin{array}{c}0.015 \\
(4.58)^{* * *}\end{array}$ & $\begin{array}{c}0.012 \\
(3.73) * * * \\
-0.003 \\
(-0.64)\end{array}$ & $\begin{array}{c}0.015 \\
(5.30)^{* * *}\end{array}$ \\
\hline Dummy_1998 & $\begin{array}{l}-0.027 \\
(-0.41) \\
0.038 \\
(0.57)\end{array}$ & & & & & & $\begin{array}{l}0.004 \\
(0.05) \\
0.011 \\
(0.15)\end{array}$ & $\begin{array}{c}0.751 \\
(3.99)^{* * *} \\
1.130 \\
(6.18)^{* * *}\end{array}$ & \\
\hline Observations & 101 & 101 & 101 & 101 & 103 & 112 & 112 & 101 & 105 \\
\hline $\mathrm{R}^{2}$ & 0.98 & 0.98 & 0.97 & 0.97 & 0.97 & 0.98 & 0.98 & 0.98 & 0.97 \\
\hline
\end{tabular}

Robust standard errors; t-statistics in parentheses

$*, * *, * * *$ respectively significant at $10 \%, 5 \%$ and $1 \% ;{ }^{\#}$ Instruments:?,

Table 4: FDI flows and Exchange Rate Volatility

\begin{tabular}{|c|c|c|c|c|c|c|}
\hline & $\mathrm{OLS}+\mathrm{FE}$ & $\mathrm{OLS}+\mathrm{FE}$ & $\mathrm{OLS}+\mathrm{FE}$ & $\mathrm{OLS}+\mathrm{FE}$ & $\mathrm{OLS}+\mathrm{FE}$ & $\mathrm{OLS}+\mathrm{FE}$ \\
\hline Zscore & $\begin{array}{l}-0.008 \\
(-2.12)^{* *}\end{array}$ & $\begin{array}{l}-0.008 \\
(-2.06) * *\end{array}$ & $\begin{array}{l}-0.007 \\
(-2.07)^{* *} \\
-0.027\end{array}$ & $\begin{array}{l}-0.008 \\
(-2.19)^{* *}\end{array}$ & $\begin{array}{l}-0.008 \\
(-2.24)^{* *} \\
0.509\end{array}$ & $\begin{array}{l}-0.006 \\
(-1.88)^{*}\end{array}$ \\
\hline GDP & $\begin{array}{l}0.336 \\
(0.54)\end{array}$ & & $(-0.04)$ & $\begin{array}{l}0.698 \\
(7.44) * * *\end{array}$ & $(0.79)$ & $\begin{array}{l}0.191 \\
(0.31)\end{array}$ \\
\hline GDP_capita & $\begin{array}{l}0.010 \\
(3.46)^{* * *}\end{array}$ & $\begin{array}{l}0.009 \\
(3.39)^{* * *}\end{array}$ & & $\begin{array}{l}0.010 \\
(3.87)^{* * *}\end{array}$ & $\begin{array}{l}0.0112 \\
(4.61)^{* * * *}\end{array}$ & $\begin{array}{l}0.010 \\
(3.57)^{* *}\end{array}$ \\
\hline Openness & $\begin{array}{l}0.331 \\
(0.56)\end{array}$ & $\begin{array}{l}0.624 \\
(6.20)^{* * *}\end{array}$ & $\begin{array}{l}0.873 \\
(1.53)^{* * *}\end{array}$ & & $\begin{array}{l}0.174 \\
(0.29)\end{array}$ & $\begin{array}{l}0.469 \\
(-2.62) \\
0.000\end{array}$ \\
\hline Interaction & & & & & & $(-2.62) * * *$ \\
\hline Financial & 0.010 & 0.010 & 0.032 & 0.010 & & 0.010 \\
\hline Freedom & $\begin{array}{l}(0.60) \\
0.301\end{array}$ & $\begin{array}{l}(0.61) \\
0.030\end{array}$ & $\begin{array}{l}(2.16)^{* *} \\
0.193\end{array}$ & $\begin{array}{l}(0.60) \\
0.303\end{array}$ & 0.320 & $\begin{array}{l}(0.63) \\
0.307\end{array}$ \\
\hline Dummy_1998 & $\begin{array}{l}(1.54) \\
0.033 \\
(0.26)\end{array}$ & $\begin{array}{l}(1.58) \\
0.023 \\
(0.17)\end{array}$ & $\begin{array}{l}(1.05) \\
-0.061 \\
(-0.44)\end{array}$ & $\begin{array}{l}(1.52) \\
0.048 \\
(0.37)\end{array}$ & $\begin{array}{l}(1.58) \\
0.047 \\
(0.38)\end{array}$ & $\begin{array}{l}(1.59) \\
0.007 \\
(0.05)\end{array}$ \\
\hline Observations & 120 & 120 & 120 & 120 & 122 & 120 \\
\hline $\mathrm{R}^{2}$ & 0.83 & 0.83 & 0.82 & 0.83 & 0.84 & 0.83 \\
\hline
\end{tabular}

Robust standard errors; t-statistics in parentheses

$*, * *, * * *$ respectively significant at $10 \%, 5 \%$ and $1 \%$; 
Table 5: Current Account and Exchange Rate Volatility

\begin{tabular}{|c|c|c|c|c|c|c|c|c|c|c|c|}
\hline & $\begin{array}{l}\text { OLS } \\
+\mathrm{FE}\end{array}$ & $\begin{array}{l}\text { OLS } \\
+ \text { FE }\end{array}$ & $\begin{array}{l}\text { OLS } \\
+ \text { FE }\end{array}$ & $\begin{array}{l}\text { OLS } \\
+\mathrm{FE}\end{array}$ & $\begin{array}{l}\text { OLS } \\
+\mathrm{FE}\end{array}$ & $\begin{array}{l}\text { OLS } \\
+ \text { FE }\end{array}$ & $\mathrm{OLS}+\mathrm{FE}$ & $\mathrm{OLS}+\mathrm{FE}$ & $\begin{array}{c}\text { OLS } \\
+\mathrm{FE}+ \\
\text { time FE }\end{array}$ & $2 \mathrm{SLS}^{\#}$ & $\operatorname{AR}(1)$ \\
\hline & 0.542 & 0.430 & 0.423 & 0.630 & 0.495 & 0.431 & 0.471 & 0.506 & 0.532 & 0.549 & 0.300 \\
\hline Zscore & $(3.08) * * *$ & $(2.50)^{* *}$ & $(2.82) * * *$ & $(3.46) * * *$ & $(3.36) * * *$ & $(2.43)^{* *}$ & $(2.63) * * *$ & $(3.49) * * *$ & $(2.69)^{* * *}$ & $(2.79) * * *$ & $(1.76)^{*}$ \\
\hline & 3.264 & & 2.986 & 3.679 & 3.253 & 3.466 & 2.736 & 3.207 & 3.012 & 3.890 & 2.776 \\
\hline Relative_income & $(4.04)^{* * *}$ & & $(3.78) * * *$ & $(4.37)^{* * *}$ & $(4.06)^{* * *}$ & $(3.67) * * *$ & $(3.47) * * *$ & $(4.47) * * *$ & $(318) * * *$ & $(4.85)^{* * *}$ & $(2.34)^{* *}$ \\
\hline $\begin{array}{l}\text { Relative_income- } \\
\text { squard }\end{array}$ & $\begin{array}{c}-12.805 \\
(-4.10) * * *\end{array}$ & & $\begin{array}{c}-11.656 \\
(-3.83) * * *\end{array}$ & $\begin{array}{c}-14.616 \\
(-4.54) * * *\end{array}$ & $\begin{array}{c}-12.766 \\
(-4.11) * * *\end{array}$ & $\begin{array}{c}-14.090 \\
(-3.83) * * *\end{array}$ & $\begin{array}{c}-10.781 \\
(-3.53) * * *\end{array}$ & $\begin{array}{c}-12.581 \\
(-4.51) * * *\end{array}$ & $\begin{array}{c}-12.090 \\
(-3.34) * * *\end{array}$ & $\begin{array}{c}-15.136 \\
(-4.78) * * *\end{array}$ & $\begin{array}{c}-11.358 \\
(-1.54)\end{array}$ \\
\hline Growth & $\begin{array}{l}-12.634 \\
(-2.01)^{*}\end{array}$ & $\begin{array}{l}-8.661 \\
(-1.30)\end{array}$ & & $\begin{array}{l}-11.067 \\
(-1.67)^{*}\end{array}$ & $\begin{array}{c}-13.712 \\
(-2.78)^{* * *}\end{array}$ & $\begin{array}{c}-17.490 \\
(-2.61)^{* * *}\end{array}$ & $\begin{array}{l}-13.824 \\
(-2.17)^{* *}\end{array}$ & $\begin{array}{l}-12.326 \\
(-1.88)^{*}\end{array}$ & $\begin{array}{l}-7.594 \\
(-0.95)\end{array}$ & $\begin{array}{c}-12.554 \\
(-2.22)^{* *}\end{array}$ & $\begin{array}{l}-8.360 \\
(-1.54)\end{array}$ \\
\hline FDI_inflows & $\begin{array}{c}-1.294 \\
(-2.22)^{* *}\end{array}$ & $\begin{array}{c}-1.737 \\
(-3.35)^{* * *}\end{array}$ & $\begin{array}{c}-1.165 \\
(-1.99)^{* *}\end{array}$ & & $\begin{array}{c}-1.337 \\
(-2.28)^{* *}\end{array}$ & $\begin{array}{c}-1.096 \\
(-1.68)^{*}\end{array}$ & $\begin{array}{c}-1.416 \\
(-2.44)^{* *}\end{array}$ & $\begin{array}{c}-1.324 \\
(-2.64) * * *\end{array}$ & $\begin{array}{c}-1.310 \\
(-2.06)^{* *}\end{array}$ & $\begin{array}{c}-1.380 \\
(-2.64)^{* * *}\end{array}$ & $\begin{array}{l}-0.466 \\
(-0.90)\end{array}$ \\
\hline Inflation & $\begin{array}{l}-0.006 \\
(-0.37)\end{array}$ & $\begin{array}{l}-0.003 \\
(-0.19)\end{array}$ & $\begin{array}{c}-0.026 \\
(-2.39)^{* *}\end{array}$ & $\begin{array}{l}-0.016 \\
(-0.89)\end{array}$ & & $\begin{array}{l}0.013 \\
(0.83)\end{array}$ & $\begin{array}{l}0.003 \\
(0.20)\end{array}$ & $\begin{array}{l}-0.004 \\
(-0.28)\end{array}$ & $\begin{array}{l}-0.016 \\
(-0.81)\end{array}$ & $\begin{array}{l}-0.008 \\
(-0.45)\end{array}$ & \\
\hline & $\begin{array}{c}-0.015 \\
(-3.52) * * *\end{array}$ & $\begin{array}{c}-0.100 \\
(-5.06)^{* * *}\end{array}$ & $\begin{array}{c}-0.106 \\
(-3.66) * * *\end{array}$ & $\begin{array}{c}-0.089 \\
(-3.69)^{* * *}\end{array}$ & $\begin{array}{c}-0.093 \\
(-3.65)^{* * *}\end{array}$ & & $\begin{array}{c}-0.090 \\
(-3.30)^{* * *}\end{array}$ & $\begin{array}{c}-0.095 \\
(-3.48)^{* * *}\end{array}$ & $\begin{array}{c}-0.084 \\
(-2.84)^{* * *}\end{array}$ & $\begin{array}{c}-0.107 \\
(-4.43)^{* *}\end{array}$ & $\begin{array}{c}-0.054 \\
(-173)^{*}\end{array}$ \\
\hline Deficit_GDP & $\begin{array}{l}0.050 \\
(0.25)\end{array}$ & $\begin{array}{l}-0.074 \\
(-0.36)\end{array}$ & $\begin{array}{l}-0.052 \\
(-0.25)\end{array}$ & $\begin{array}{l}0.024 \\
(0.12)\end{array}$ & $\begin{array}{l}0.028 \\
(0.15)\end{array}$ & $\begin{array}{l}0.061 \\
(0.29)\end{array}$ & $\begin{array}{l}0.023 \\
(0.20)\end{array}$ & & $\begin{array}{l}0.124 \\
(0.54)\end{array}$ & $\begin{array}{l}0.042 \\
(0.22)\end{array}$ & \\
\hline Openness & $\begin{array}{l}-0.498 \\
(-0.16)\end{array}$ & $\begin{array}{l}1.908 \\
(0.62)\end{array}$ & $\begin{array}{l}-0.758 \\
(-0.25)\end{array}$ & $\begin{array}{l}-3.269 \\
(-1.18)\end{array}$ & $\begin{array}{l}-0.347 \\
(-0.11)\end{array}$ & $\begin{array}{l}1.461 \\
(0.42)\end{array}$ & $\begin{array}{l}1.238 \\
(0.41\end{array}$ & & $\begin{array}{l}-5.454 \\
(-1.39)\end{array}$ & $\begin{array}{l}-1.565 \\
(-0.56)\end{array}$ & \\
\hline Capital Control & $\begin{array}{c}-0.091 \\
(-2.69)^{* * *}\end{array}$ & $\begin{array}{l}-0.039 \\
(-1.05)\end{array}$ & $\begin{array}{c}-0.099 \\
(-2.92)^{* * *}\end{array}$ & $\begin{array}{c}-0.010 \\
(-3.07)^{* * *}\end{array}$ & $\begin{array}{c}-0.088 \\
(-2.66)^{* * *}\end{array}$ & $\begin{array}{c}-0073 \\
(-1.83)^{*}\end{array}$ & & $\begin{array}{c}-0.090 \\
(-2.95)^{* * *}\end{array}$ & $\begin{array}{c}-0.104 \\
(-2.54)^{* * *}\end{array}$ & $\begin{array}{l}-0.101 \\
(-2.49)^{* *}\end{array}$ & \\
\hline Observations & 113 & 113 & 113 & 114 & 113 & 113 & 113 & 113 & 113 & 112 & 104 \\
\hline $\mathrm{R}^{2}$ & 0.74 & 0.69 & 0.73 & 0.73 & 0.74 & 0.69 & 0.73 & 0.74 & 0.77 & 0.69 & $0.41^{\# \#}$ \\
\hline
\end{tabular}

F-country fe

Robust standard errors; $t$-statistics in parentheses

${ }^{*}, * *, * * *$ respectively significant at $10 \%, 5 \%$ and $1 \% ;{ }^{\#}$ Instruments: Exchange rate volatility, ${ }^{\# \#} \mathrm{R}^{2}$ within, 